\title{
People in Villages: Micro-Level Studies in Political Economy
}

\section{Citation}

Bates, Robert H. 1978. "People in Villages: Micro-Level Studies in Political Economy." World Pol. 31 (01) (October): 129-149.

\section{Published Version}

doi: $10.2307 / 2009970$

\section{Permanent link}

http://nrs.harvard.edu/urn-3:HUL.InstRepos:12211499

\section{Terms of Use}

This article was downloaded from Harvard University's DASH repository, and is made available under the terms and conditions applicable to Other Posted Material, as set forth at http:// nrs.harvard.edu/urn-3:HUL.InstRepos:dash.current.terms-of-use\#LAA

\section{Share Your Story}

The Harvard community has made this article openly available.

Please share how this access benefits you. Submit a story.

\section{Accessibility}




\title{
PEOPLE IN VILLAGES: \\ Micro-level Studies in Political Economy
}

\author{
By ROBERT H. BATES
}

Walter Barrows, Grassroots Politics in an African State: Integration and Development in Sierra Leone. New York: Holmes and Meier; London: Africana Publishing Co., I976, 265 pp., \$25.00.

Björn Beckman, Organizing the Farmers: Cocoa Politics and National Development in Ghana. New York: Holmes and Meier; Uppsala: Scandinavian Institute of African Studies, I976, 299 pp., \$16.20 (paper).

John Dunn and A. F. Robertson, Dependence and Opportunity: Political Change in Ahafo. African Studies Series 9, New York and London: Cambridge University, 1974, 400 pp., \$21.00.

James R. Finucane, Rural Development and Bureaucracy in Tanzania: The Case of Mwanza Region. New York: Holmes and Meier; Uppsala: Scandinavian Institute of African Studies, I974, I92 pp., \$12.50 (paper).

Donal B. Cruise O'Brien, Saints and Politicians: Essays in the Organization of a Senegalese Peasant Society. African Studies Series 15, New York and London: Cambridge University Press, 1975, 213 pp., \$1 3.95.

Maxwell Owusu, Uses and Abuses of Political Power: A Case Study of Continuity and Change in the Politics of Ghana. Chicago and London: University of Chicago Press, I970, 364 pp., \$12.75.

James C. Scott, The Moral Economy of the Peasant: Rebellion and Subsistence in Southeast Asia. New Haven: Yale University Press, 1976, 246 pp., \$15.00.

\section{INTRODUCTION}

T $\mathrm{N}$ recent years, social scientists have produced studies of village com1 munities in the developing areas which, on the one hand, exceed in scope the classically narrow focus of social anthropology, while on the other remaining more intensively micro-level than is traditional for works in political science. This new genre is now large enough to warrant description and appraisal.

I should note at the outset that this essay is primarily intended to give structure to the new literature and not to criticize it. In keeping with this purpose, I may be ascribing greater clarity to some of these works than they in fact possess, and I have occasionally withheld crit-

* I wish to acknowledge the comments of Morris Fiorina, John Ferejohn, Morgan Kousser, Bruce Cain, Gary Miller, Thayer Scudder, and David Laitin. Particularly helpful were the comments of Roger Noll and Samuel Popkin. I also want to acknowledge the financial assistance of the National Science Foundation (Grant NSF 4 SOC 77-08573).

(C) 1978 by Princeton University Press

World Politics 0043-8871/78/0101 29-21 \$1.05/I

For copying information, see contributor page 
icism where it is in fact warranted. I have placed greater importance on trying to impart structure and coherence to this new literature than on trying to point out its deficiencies.

In section II, I examine the central issues that characterize this literature, and note a series of debates that run through it. Taken in conjunction, the debates underscore apparent inconsistencies which, in section III, I attempt to define and resolve. I conclude by specifying a research agenda for this emerging subdiscipline.

\section{The Central Concerns of the Literature}

Micro-level studies are characterized by their attempts to analyze the politics of the developing nations through an examination of local communities (which in the cases reviewed here are rural ones), their environment, and the relationships they bear to their environment. More explicitly, the studies attempt to analyze the politics of the developing areas by seeking answers to the following questions:

With respect to the environment: From the point of view of the residents of the rural communities in the developing areas, what features of their political and economic environment make the most significant impact upon their welfare? How can this environment best be characterized?

With respect to the local community: What are the most significant features of the structure of the local community? What do its members want? What appears to determine their behavior? In particular, what appears to determine the way in which they respond to the dominant forces intruding from the environment of their communities?

With respect to outcomes: What evaluations are to be made of the development process on the basis of the evidence disclosed in these studies? And on what grounds are such normative judgments to be formed?

\section{A. THE ENVIRONMENT OF THE RURAL COMMUNITIES}

The external forces that appear to make the strongest impact on the local village communities and most critically to determine the welfare of the people therein are two in number; they are the state and the market.

Scott examines the formation of the colonial order in Southeast Asia, the creation of new institutions and, especially, new forms of local administration and taxation, as well as the resultant disruption of the 
political economy of the villages. He also analyzes the spreading commercialization of agriculture and the move to a cash-crop economy, geared to production for the world market. He relates the peasants' political and economic behavior to their attempts to maintain their wellbeing in the face of what they experience as uncontrollable fluctuations in that market; in particular, he focuses on the rebellions associated with the Great Depression. Similarly, O'Brien analyzes the rise of French colonialism in western Africa and the penetration of world markets into the Sahelian countryside; he too identifies colonial intervention and cash-crop production as the major exogenous forces determining the course of politics in the area. Dunn and Robertson and Maxwell Owusu retell the story in a Ghanaian setting, describing the growth of the colonial order in this small segment of the British Empire and focusing on the response of local villagers to the rising demand for cocoa in the world's commodity markets.

Again and again, micro-level studies designate the state and the market as the sources of the major exogenous shocks that set social and political forces moving in the rural areas and that thereby account for much of the political activity among the agrarian population of the developing nations. What is particularly interesting, however, is not the existence of this consensus; rather, it is the debate that emerges within it concerning the best ways in which to characterize these forces and the nature of their impact.

One debate centers on the question whether, in their encounter with these external forces, rural folk are willing accomplices or passive victims. Within the marketplace, rural dwellers are rarely rich; many of the benefits of their exchanges in the world market are captured by others. And within the state, rural dwellers do appear to lack power; the policies of states, as recorded in these volumes, cannot have been constructed with their interests primarily in mind. Surely then, they ought to be seen as victims. The thesis of victimization is most strikingly developed by Scott, who, as his main task, examines the moral economy of the peasantry, which he defines in part as "their working definition of exploitation" (p. 4). In his conception of peasant victimization, Scott is of course joined by a host of others; the notion of the peasant as victim is a central theme in this field. ${ }^{1}$

And yet, a strong countercurrent runs through these studies: one that

${ }^{1}$ Perhaps the best review and critique of this literature is contained in Samuel L. Popkin, The Rational Peasant: The Political Economy of Rural Change in Vietnam (Berkeley and Los Angeles: University of California Press 1978). The book is also important for the contribution it makes to developing rational models of collective behavior in peasant society. 
emphasizes the willingness and ability of rural folk to manipulate and exploit external forces-to conjure them up, even, and to channel them in directions that redound to their advantage. Thus, the inhabitants of Ahafo (who form the center of Dunn and Robertson's study) actually called in the British colonists in order to advance their cause in their political struggles with the Ashanti. The book is also concerned with the energies the people of Ahafo have expended to mine their forests for products of value in the international market. Similarly, the Wolof peasants studied by O'Brien entered into a political alliance with the French so as to protect themselves from the slave traders; and their efforts to promote the peanut trade in Senegal, and to influence the locational decisions of French transport planners, constitute evidence of the strength of the capitalist ethic in this supposedly pre-market society.

The evidence of these studies thus falsifies any notion of the peasantry as a passive victim. The problem of reconciling the poverty of the peasants with their proven canniness as politicians and entrepreneurs will therefore continue to stimulate debate concerning the proper characterization of their encounter with the political and economic forces that have intruded upon them.

A second debate centers on the proper characterization of the state: Is it a monolith or an arena for political competition? The various authors appear to be fundamentally inconsistent in their own minds as to what the answer should be. Finucane, for example, repeatedly stresses the lack of meaningful political participation in the Mwanza district of Tanzania. But the material he presents in his discussion of the role of the parliamentarian suggests that real resources are at risk in the political system, that elites compete in efforts to supply these resources, and that rural dwellers exploit this competition in order to elicit material benefits from the state.

The image conveyed by O'Brien is even more inconsistent. In chapter four, he documents the successful monopolization of rural markets by the state and its consequent ability to extract surpluses from the peasant economy; in chapter five, however, he describes the spirited political rivalries among the national elites of Senegal and the enormous diversions of public resources to the countryside that result from the efforts of the rural dwellers to exploit these rivalries. Beckman, in his sixth chapter, reveals a similar ambivalence.

Conflicting evidence thus leaves open the debate concerning the proper characterization of the state. The stakes in this controversy are high. For if the state is a monolith and is impervious to the wiles of 
the peasantry, a necessary condition is fulfilled for a class analysis. But if the state is a competitive arena, the peasantry can more properly be viewed as one of several interested claimants for public resources; in that case, the peasantry is an interest group. Depending on the way in which the debate is resolved, then, very different kinds of analyses and normative judgments will obtain. In section III, I entertain a heretical middle ground and examine the possibility that the state can be both a monolith (on the revenue side) and an arena for competitive politics (on the expenditure side), and I show how such a realization clarifies many of the ambiguities in these studies.

The last item of controversy concerns the proper characterization of the market. Again, the debate tends to collapse around an oversimplified set of choices. On one side, some authors-in the case of the books at hand, Scott in particular-tend to see the market as a milker of rural resources. On the other, Owusu and Dunn and Robertson view the market as a provider of material benefits. Naturally, however, the market is both things, for it is an arena for exchange. In the literature at large, taste and ideological predisposition tend to determine which side of the exchange receives primary emphasis. As the debate is based so largely on differences in values, it promises to be interminable, and will therefore continue to provide a central focus in the field.

\section{B. THE LOCAL COMMUNITY}

I. Social structure and resource allocation. The first set of questions focuses our attention on the interactions between the local community and its environment; the second set leads us to search more closely within the village setting. Through this literature we are introduced to a highly diverse cast of characters and vigorously conflicting sets of interests. Naturally, there are the peasants: some merely subsist, some produce for the market, and some alternate between these roles. Some have large farms, and some have small ones; some own capital equipment, others do not. Among the persons without farms, the landless laborers are the most significant. There are traders: some sell products from the city, some buy produce from the farm, some do both; many offer credit. There are religious leaders. There are headmen and chiefs. There are also "strangers" and "sons of the soil"-immigrants and citizens of the local areas. Among these social categories, there is little identity of interest. The scarcity of land induces conflicts among them; so do questions concerning relative prices in the marketplace and the distribution of the costs and benefits of public programs.

Aside from concurring on the diversity of interests in the countryside, 
the authors of these micro-studies agree that social rank constitutes the most significant dimension for differentiating among these groups. Scott distinguishes principally between the landlords and tenants, and the patrons and clients, in Southeast Asia. For Owusu, Barrows, and Dunn and Robertson, the chief emerges as the principal elite figure in the West African countryside; for Finucane, it is the bureaucrat or the prosperous farmer. To Western minds, O'Brien's saints will no doubt be most intriguing: religious leaders of the Tijaniyya sect in Senegal who combine agrarian wealth with political savvy, and thus emerge as the machine politicians of the rural sector of that nation. All of the authors designate disparities in wealth, power, and social status as the primary basis for the diversity of interests in the rural areas of the developing nations.

A major issue then arises in this literature: Does inequality-which, as all agree, exists-imply exploitation? The answer appears to depend upon the degree of competition within the highest stratum. When competition within the rural elite is constrained, the less privileged are exploited. When the members of the elite have to compete for positions of prominence, however, rival claimants for elite status must use their positions of prominence to extract and distribute benefits and thereby build a following. Competition within the elite thus counters the potential for exploitation. The contrast between the period of colonial rule and the period of nationalist politics is illustrative of the importance of these considerations.

In Africa, colonial officials implemented measures that curtailed the degree of competition for chiefly office. In one particularly striking illustration, Barrows shows how the British invented the "traditional" rules of succession of office-rules that made the accession to office contingent upon a genealogical order of succession rather than upon securing the support of a majority in the relevant public councils. ${ }^{2} \mathrm{~A}$ similar pattern prevailed in Southeast Asia: according to Scott, as competition for elite positions decreased in the colonial period, the elites

${ }^{2}$ As a result of isolating the process of succession from the distribution of preferences among the kingdom's citizenry, the rigid rules of genealogical determinism permitted the adoption of unpopular policies. Ironically, while the rules were adopted in part to increase predictability in public affairs, they did in fact lead to radical shifts in public policy. The rules determined who secured office but did not determine what the officeholders' policies would be. Under more democratic procedures, of course, the content of policy would be determined-it would be the policy of the legendary median voter; the winning candidate would be indeterminate-it would be whoever selected the median policy position. See Phyllis Ferguson and Ivor Wilks, "Chiefs, Constitutions, and the British in Northern Ghana," in Michael Crowder and Obaro Ikime, eds., West African Chiefs: Their Changing Status Under Colonial Rule and Independence (New York: Africana Publishing Company I970), 326-69. 
were able at last "to realize the full exploitative potential of their bargaining power..." (p. 65) - a potential which, he feels, had previously existed but had never before been fully realized.

The colonial period was thus characterized by elite cohesion and a movement from inequality to exploitation. One major result was rural rebellion and the participation of rural dwellers in the mid-century nationalist movements. Their prime objective, by all accounts, was the desire for access to resources whose allocation was controlled by the more privileged stratum; as a major technique, they engendered competition between members of the rural elite. In Sierra Leone and Ghana, for example, rival factions contested for chiefly thrones; many chiefs failed to serve out their full terms of office; and all contestants apparently felt compelled to deliver benefits in the form of jobs, money, public works, or legal commitments. In Senegal, O'Brien reports, the followers had strong expectations of material benefits from their "saints"; "where this hope is consistently disappointed, in the last resort they may (and do) change their allegiance to a more favorably placed local leader; no saint can afford a record of failure ..." (p. I77). In Southeast Asia, patrons appeared to compete for clients and strove to generate benefits with which to secure popular backing. Inequality remained; but competition for privileged positions within the system of rural stratification appeared to generate benefits for the relatively disadvantaged.

In the post-independence period, the pattern of competition and participation took place in the face of public policies designed to discourage it. The formation of single-party states, the administrative selection of local government leaders, the formation of bureaucratic monopolies to administer the trade and taxation of agricultural products-these were measures through which Ghana, Senegal, Tanzania, and other states sought to reduce competition, curtail participation, and thereby achieve the ability to implement policies that allowed them to appropriate the revenues generated by the peasants' production. It is not clear how successful this strategy has been, either in constraining participation or in contributing to major income transfers from the countryside. The present studies document that at both the national and local levels, competition among elites persists. They reveal the tendency for dissident national and local elites to form alliances and to compete for support in the rural sector; indeed, the analysis of these alliances forms the core of Barrows's and O'Brien's books. The result of this competition is the distribution, through public channels, of major amounts of resources in the form of credit, jobs, material benefits, and 
public works. Rural participation persists and material benefits are provided for the peasants-even while pricing and taxing policies are implemented that violate their interests. Official measures seek to constrain the peasants' ability to use agencies of political participation to oppose these policies. Again, the conflict between the images of exploitation by the state and its provision of benefits remains a major puzzle in this literature.

2. Models of peasant behavior. In focusing scholarly attention upon the rural sector of the developing areas, micro-level studies emphasize the structure of rural communities and illustrate its importance to the allocation of material resources. In adopting a micro-perspective, the authors of these studies also tend to focus upon individuals and individual behavior, albeit often while using the family or household as the basic unit of analysis. They employ a variety of models of individual behavior. The use of such models is significant since the selection the authors make among alternative representations is in itself informative; moreover, the use of models makes it possible to relate diverse and seemingly unconnected areas of behavior and to form testable propositions.

In explicitly formulating models of individual behavior, the students of micro-level politics make a significant choice right at the start: they unanimously discard the image of traditional man that has so often been used in the development literature. The peasant who would fail to innovate for fear of violating some time-honored practice; who would pass up an opportunity for individual gain out of regard for the welfare of the larger community; or who is so imbued with religious values that he would shun the attractions of material progress-none of these figures is to be found in these studies. And where related figures are found, as in O'Brien's study of the Mouride brotherhood, they are treated with deep skepticism. ${ }^{3}$ Rather, the kind of rural dweller encountered in these micro-studies is a person making choices out of a regard for his own interests.

${ }^{3}$ It has been pointed out that Scott's model does emphasize unwillingness to innovate, other-regarding behavior, and shunning of material gain. True. But Scott's model is one of individual rationality, and it allows him to derive and to account for these kinds of behavior. He attempts to explain them, rather than positing them as inherent tendencies. In this, Scott differs from earlier writers on "traditional man," who built similar behavioral tendencies into their basic model. Unlike his predecessors, Scott is able to argue that under different circumstances, persons behaving in the risk-averse manner he describes will no longer insure themselves by observing the norm of reciprocity, etc.; when such behaviors are built into the model, however, there is no latitude for predicting that they will change. Scott's approach can thus be considered to be qualitatively different from that of his predecessors, despite the apparent similarities. 
Within this revisionist position, however, there are basic differences. For Owusu, the appropriate model appears to be one of income maximization. The desire for greater income, he argues, led the peasants of Swedru (the rural area which he studied) uncritically to embrace the economic opportunities presented to them by the world market for cocoa and to engage in political action in pursuit of material gain. In Ghana, Owusu notes, "Political power was not sought for its own sake; even Nkrumah's 'Seek ye first the political kingdom' was only a means to all the good material things which 'shall be added unto' Ghanaians. ... Political relations seem to have had no meaning except in terms of property and wealth" (p. I7I).

It is clear why Owusu is tempted to posit income maximization as an appropriate objective. In Swedru-as in Ahafo, Senegal, Mwanza, Burma, and Vietnam-many of the fundamental political conflicts do indeed reduce to struggles for greater income and for the resources by which it can generate. The price of agricultural products and manufactured goods, the level of rents and taxes, the provision of roads, markets, and public services-these are among the fundamental political issues in the countryside, and all gain their importance primarily through their impact upon personal incomes. In recognizing the importance of economic self-interest in rural politics, and in positing that people make choices so as to enhance their incomes, Owusu, Barrows, and others specify a highly plausible approximation of a valid model of peasant behavior. ${ }^{4}$

It is instructive, however, that Owusu repeatedly appears to find his model of income maximization too confining; again and again, he slips over into a model of utility maximization which holds that the primary objective of the residents of Swedru was not greater income, but the increased satisfaction they would derive from the increased consumption of the good things of life. Indeed, Owusu at one point contends that the primary goals of rural dwellers are "high status, social recognition, and social dignity" (p. 5); the attempts to gain increased income represent attempts to gain the resources through which better to achieve these ultimate objectives.

The distinction is important, for utility maximization and income maximization constitute sharply different models and create different expectations about how people will behave; we should be able to choose between them. Do people in fact surrender opportunities for increased

${ }^{4}$ I have used this model myself, and am therefore subject to the same criticisms that I will make of these other works. See Bates, Rural Responses to Industrialization: A Study of Village Zambia (New Haven and London: Yale University Press 1976). 
income out of a regard for other values? Do they work, for example, until the monetary value of their marginal product is zero? Or do they place a positive value on other uses of their time? Can they be compensated for losses of income by higher office or enhanced prestige? Particularly in the area of politics, the models create different expectations. Presumably there are circumstances under which an income-maximizing politician would sell his policy position to the highest bidder. Depending on his preferences, there are conditions under which the utilitymaximizing politician would refuse such bids. If he derives satisfaction from holding office, he would not accept a bribe to adopt a position that would threaten him with loss of office. Alternatively, he would refuse a bribe if it were intended to secure his active opposition to a policy to which he had a strong personal commitment. Owusu's study and others suggest, alas, that there is ample opportunity to test out these divergent expectations.

Another modification of the income-maximization model should be considered, and this is where Scott's book makes its fundamental contribution. Alternatives, and in particular alternative incomes, do not present themselves with certainty; rather, they come with probabilities attached. In light of this, Owusu's initial position could be modified to hold that, behaving as income maximizers, rural dwellers would choose among alternatives so as to maximize their expected incomes. Scott would register a sharp dissent. He contends that many peasants cannot really afford to gamble. They are poor and they must safeguard their level of subsistence. As a result, they would choose among uncertain alternatives not only in terms of their expected values but also in terms of their dispersions. An alternative which has a greater expected payoff, but also a greater probability of driving a peasant below his subsistence level, will, according to Scott, be forsaken for one which on average promises less, but which would guarantee a minimum subsistence level.

Scott's revision of the income maximization hypothesis succeeds in some areas where Owusu's position fails. On average, peasants would do better monocropping; instead, they often tend to mix their crops. As a result, they often do less well, but they also less frequently starve. On average, most peasants would be better off with consolidated fields; but many prefer to hold scattered plots, each with a different type of soil. Again, the result is a lower average income, but a hedge against "downside risks." Instead of specializing in cash crops, most peasants devote part of their resources to making subsistence gardens, thus lowering their average income but insuring themselves against starva- 
tion. These and many other well-known features of rural economic behavior defy a model based upon the maximization of expected income; but they conform to the expectations generated by a model of utility maximization that makes allowances for an aversion to risk. ${ }^{5}$

When applied to agrarian politics, the notion of risk aversion is also useful. Clearly, peasants do organize politically in efforts to transfer risks. Farmers everywhere have favored government guarantees of minimum prices and the public subsidization of the risks of farming; in the United States, the public has paid an enormous price to fulfill these demands. Moreover, as Scott argues, peasants appear to prefer variable as opposed to "straight line" taxes; progressive taxes, for example, may levy more on average, but they are forgiving of peasants laboring near the subsistence margin. And peasants have repeatedly sought political intervention to modify contracts that threaten to drive their members below a guaranteed subsistence level, be they mortgages, tenancy agreements, or the investiture of private rights on public commons (Scott, 29ff.). A model of risk aversion clearly offers insight into the political as well as the economic behavior of peasants.

Scott's model thus holds great promise. But it must be handled with some caution. When taken to an extreme, it does break down. And, although one may agree with-and applaud-this model in its essentials, it does seem incomplete.

Scott's model cannot be interpreted to imply that, if an alternative poses any finite probability of going below subsistence level, it will not be chosen. When taken to this extreme, Scott's model would suggest that peasants make no use of information regarding relative probabilities, and it would predict inaction. Rather, the model must be construed as stating that peasants will prefer those alternatives which offer the

${ }^{5}$ At this point we may note that Scott and many others are guilty of a major error. Peasants, it is contended, seek to keep the external market at arm's length and to use only local markets; for, it is held, the external market is subject to uncontrollable fluctuations. It is true that fluctuations cannot be controlled in the larger, external market; but they will be smaller. If it is risks that the peasants seek to avoid, they should therefore prefer to trade in larger markets.

The reasons the fluctuations will be smaller are as follows: concentrating on the supply side, say that the primary determinant of the level of supply is the occurrence of droughts. The larger the market, the greater the chance that at least some suppliers will be spared; products can then be moved into areas where they are relatively scarce and therefore command higher prices; this movement will continue to take place until the products command the same price everywhere, save for the cost of transport. The result of the movement of goods is thus a dampening of the rise in prices. Where the market is small, however, the chances are greater that all suppliers will be affected, and no movement of goods could reduce the rise in prices. Although this extreme case is rare, insofar as it is approximated, price rises will be greater. If they prefer small fluctuations, peasant consumers would then prefer larger markets. 
lowest probability of driving them below a particular income level. If his analysis is to be useful, probabilities must feature in his analysis.

Moreover, Scott's model should not be construed as arguing that peasants will minimize the probability of falling below subsistence at any price. For we know from O'Brien's study that, when the expected returns become sufficiently high, the Wolof peasantry did specialize in cash-crop production; moreover, they accepted the risks of monocropping. ${ }^{6}$ And Beckman's study reveals that the Ghanaian peasants refused in 1954 to take a four-year guaranteed price for their cocoa when the guaranteed price was below what they expected the world price to be. The levy proposed by the Ghana Government would have smoothed the farmers' income streams; however, it depressed their average incomes, and Beckman's account shows that the farmers therefore resisted it. In other words, the evidence suggests that peasants evaluate alternatives in terms of both moments of the income distribution. If the mean of one is high enough relative to the other, even risk-averse people may prefer it despite the fact that it may have a higher variance; for the advantage in its expected value may more than offset its disadvantage in terms of the greater probability it offers for a low return. Scott's model thus becomes invalid if it is construed as meaning that only the variance counts.

It must be noted that Scott does not take either extreme position, although he occasionally comes close. But his model does contain one flaw which is closely associated with the last point: it fails to predict that, for a very high return, peasants will in fact gamble. What, for example, could have been more of a gamble than to join in the very revolutions he describes? Did not the movement into the unoccupied lands of Chochin China represent a gamble? Is not urban migration a gamble? The fact that peasants do rebel, resettle, and migrate suggests that a model of pure risk-aversion is not a valid one. Rather, on the evidence presented, it should be modified to approximate a model of the Friedman-Savage type: one that posits a utility surface with risk-averse properties at low income levels, and risk-preferring ones at higher incomes.

3. Discussion. These models are important because, in their simplicity, they are general; areas that are conventionally regarded as unrelated, such as cropping patterns and revolution, can be related to each other

${ }^{6}$ Reports indicate that the Senegalese peanut farmers consume imported rice. I am indebted to Bruce F. Johnson for this point.

${ }^{7}$ See Milton Friedman and L. J. Savage, "The Utility Analysis of Choices Involving Risk," Journal of Political Economy, Vol. 56 (August 1948), 270-304. 
and subsumed under a more comprehensive analysis. They are relatively powerful; through the use of evidence, we can falsify them. And they allow the beginning of the construction of theory in this area of developmental politics; that, to my mind, is what the enterprise is about.

While obviously applauding the introduction of models of individual choice into this literature, I must express one major reservation. It is appropriate that I do so within the context of this section of the paper, for my objection pertains to the relationship between social structures and individual preference. The point is a simple one: there is a gap between collective and individual behavior that is treacherous and must be crossed with great care. While we may agree with Scott, for example, that peasants are risk-averse, we would be on shaky grounds indeed if we agreed with him that they therefore develop social institutions for minimizing risks.

There are several reasons why we cannot simply attribute the properties of rural institutions to the preferences of the peasants. As with most of us, so with the peasants: especially where people have the same preferences, in a world of scarcity, individual interests must conflict. We therefore cannot assume, as Scott appears to, that peasants can simply agree upon a set of social institutions to secure their common objectives. Moreover, there is little reason to suppose that rational individuals can attain socially rational outcomes. In instances where the free-rider problem exists, social and individual rationality will in fact conflict; unfortunately for the argument of Scott and others, it is precisely in the realm of politics that this problem is paramount. Finally, even if social institutions were in some way expressions of the values of society's members, the preferences of the individuals would not be sufficient to explain the existence of any particular institution. To cite an example that is not all that far-fetched, given current policy proposals in Ghana: futures markets and extended families both are means of insurance; and knowing that Ghanaian cocoa farmers are risk-averse would not explain why they take recourse to the one but fail to employ the other. For a variety of reasons, then, it is not wise, and it is probably wrong, to impute the properties of social institutions to the preferences of society's members, as Scott, for instance, repeatedly does in his work.

How, then, should we proceed? The best way is simply to avoid such reductionism. Institutions and individual preferences should be independent elements of equal standing in the arguments we wish to advance, and by combining information about both, we can seek to explain collective outcomes. For example, knowledge of the rules of landholding can be combined with information concerning the risk- 
averse tendencies of peasants to show how they insure themselves against climatic variation. Or our knowledge of the rules of genealogical succession can be pooled with information concerning the peasants' preferences to explain succession to chiefly office, and thus the choice of public policies in rural settings. Clearly, we are better off with models of individual behavior than we are without them. But it is also certain that we are on sounder ground when we combine such models with information concerning social rules and institutions than when we seek to treat social structures as "expressions" of the values of the individual members of society.

\section{NORMATIVE RESPONSES}

Finally, this literature is concerned with formulating normative judgments. Having examined the encounter of rural dwellers with the forces of the market and the state, the authors seek to judge the outcome of that engagement. In particular, they share a deep interest in the normative implications of two central phenomena in the development process: the use of coercion and the rise of inequality.

As the books make clear, the rural dwellers' encounters with the state are often unpleasant. In particular, governments can compel villagers, through a variety of devices, to surrender resources for the purpose of financing public economic programs. Coerced savings-in the name of development-are a prominent feature of the peasants' encounter with the state; they give rise to important questions of ethical justification.

In principle, the role of coercion in the amassing of savings for economic growth should pose few ethical difficulties, for, in theory, people would vountarily consent to be coerced to save in order to maximize their own satisfaction. To secure the largest feasible stream of per capita income over their planning horizon, and thereby to maximize their welfare, the members of a society must save and invest at a rate that insures that objective. But the welfare of future generations, which all supposedly value to some degree, possesses the properties of a public good. As a result, no matter how large the value placed on the welfare of future members of the society, the optimal rate of savings and investment could be chosen in a decentralized manner only under an extremely implausible set of assumptions. Coercion is thus inherent in the development process, and people could reasonably agree to be coerced to save so as to attain higher levels of satisfaction. ${ }^{8}$

\footnotetext{
${ }^{8}$ See, for example, the argument presented in Stephen Marglin, "The Social Rate of Discount and the Optimal Rate of Investment," Quarterly Journal of Economics, Vol. 77 (February 1963), 95-1 I I.
} 
In reality, of course, the ethical questions are more difficult. When separate economic sectors enter the picture, and in particular when the rural sector is considered, fundamental problems arise. Almost inevitably, development entails the transfer of resources from one sector to another; certainly, the transfer of resources from agriculture to industry has been a classic feature of the development process. With redistribution comes the end of voluntary consent as a basis for justifying coercive levies. The challenge then arises of developing a social philosophy that would give an ethical foundation for forced savings. It is obvious that we are far from possessing such a doctrine. ${ }^{9}$

The present studies do not dwell at great length on the special problems of agriculture in the development process, however. Rather, on the basis of the materials that they compile, they argue the general case. They do so on two principal grounds. The authors exhibit a profound skepticism concerning the ability of the governments of the developing nations to select the level of savings and investment that would generate an optimal consumption program. Beckman, for example, documents the near-disastrous performance of the Government of Ghana in its attempts to select an appropriate investment program. More strikingly still, virtually all of the writers query the willingness of these governments to select a socially optimal development program, as opposed to one that simply maximizes their own economic advantage. Naturally, the rural dwellers themselves share in this skepticism. With the growth of such reservations, the consensual basis for public savings erodes. The ethical basis for coerced levies thus remains to be established.

One debate thus revolves around the issue of coercion and is primarily concerned with the encounter between the peasants and the state. Another focuses primarily on the encounter between the peasants and the market; it centers on the issue of inequality. The basic question is compelling: would the transformation from a subsistence economy to one based on market exchanges receive ethical assent?

The authors of these studies would all agree that peasants did not resist the intrusion of the market. Acting on the basis of perceived

\footnotetext{
${ }^{9}$ It has been argued that the transfer of resources out of agriculture should receive the assent of the rural dwellers themselves, as they or their descendants will share in the benefits of the economic growth which these resources engender. But this argument assumes the very thing whose absence made coercion inevitable in the first place: the ability of a high regard for the welfare of future generations to induce voluntary savings. In other words, it ignores the public-goods feature of the welfare of future generations.
} 
self-interest, rural dwellers apparently embraced the opportunities initiated from without. The peasants have found, in the words of Dunn and Robertson, the results to be both "pleasant" and "useful." Materially, most are better off. But are they morally so? Dunn and Robertson doubt it. And, according to Scott, many of the peasants themselves would not think so either. While benefiting from the market, he contends, they nonetheless feel morally violated.

At the basis of the arguments of Scott, Dunn and Robertson, and others are questions involving self-interest, ethics, and the distribution of income. Self-interest instructs that when you see your opportunity to become better off, you should take it. But ethics places requirements on choices made in the absence of clear information about where one's self-interest lies. Scott and Dunn and Robertson argue that, before the arrival of the market, peasants lived in an egalitarian state in which few, if any, were rich, but no one starved. If they had been told that the result of their embracing the market was that inequality would arise, and that they would come to occupy with equal likelihood any one of the positions in the resultant wide-ranging distribution of income, would they have chosen to enter this new economic order? If, in the absence of knowledge about what their own incomes would be, they would have chosen to enter, then, the authors appear to argue, they would be behaving morally. But on what grounds would they have made such a choice?

Scott offers a model for such a choice that is near-Rawlsian in nature. To gain the approval of peasants, he argues, the new economic order must insure that the poorest in the new order would be no poorer than he had been in the society that guaranteed his subsistence. Because the world market offers no such guarantee, Scott argues, it violates the peasants' sense of ethics. Naturally, there are other viewpoints on this matter. Persons insensitive to the difference between the incomes of the very rich and the very poor could take a utilitarian view: if, on average, people are better off in the market economy, they have made a correct choice in entering it. Economists who look to efficiency as the major criterion for choice would be inclined to take such a position. Another criterion could be that the choice would be ethical only if, when any person was confronted with the benefits (or lack of benefits) reaped by another, he would be willing to change places with that other person. That is the criterion which Dunn and Robertson apparently apply.

Would the transformation from a subsistence economy to a market 
economy receive ethical assent? The central position of such normative issues in this literature is one of its major attractions.

\section{Some Conflicts Resolved}

I have isolated the major issues that underlie the literature under examination and that dominate much of the intellectual discourse within it. In outlining these debates, I have noted a variety of inconsistencies. Sometimes these arose in the form of differing viewpoints among authors; at other times they arose as seeming confusions within the writings of a single author. Taken together, they form a series of paradoxes that invite exploration.

There can be no doubt but that the regimes in the developing areas seek to capture major portions of the profits of peasant production. They maintain a tariff structure that in effect represents a tax on rural exports for the world market. They tax exports directly. They make numerous levies on the sale of cash crops. And in Senegal, Ghana, and Tanzania, they help to perpetuate monopsonies so as to force unfavorable prices on the producers and thereby capture a major portion of the gains from trade.

Despite all this, to a surprising degree, the peasants have not made the structure of taxation, tariffs, and prices the major issues in the rural politics of these areas. Clearly, for a time these issues were important in Ghana. The Convention People's Party (CPP) initially won votes in the cocoa region on the issue of cocoa prices, and later lost votes in this region when it failed to reverse the pricing policies of its colonial predecessors. What is striking, however, is that Ghana appears to represent an exception; even more to the point, the CPP was, still later, able to break the opposition in the cocoa-growing areas even while it continued to implement adverse pricing policies.

Could it be that, having been systematically bled by the state, the rural dwellers turned apathetic? Clearly, no. All of the studies disclose enormous expenditures of political energy. Could it be that they are not as materially inclined as we would have it? Again, no. The studies reveal that the peasants will fight over the level and pattern of government expenditure, the quantity and location of public projects, jobs, credit, and other things that represent the material spoils of politics. What would appear to be the case is that the rural dwellers fail to attempt to secure collective political benefits or to defend their collective interest as peasant producers for the world market; instead, they devote their ener- 
gies to attempts to secure disaggregated and divisible benefits from the state. It is also clear that the politicians promote this kind of behavior. As a result, we tend to see the politics of spoils rather than the politics of class action. ${ }^{10}$

The incentives for such behavior are clear. As recent works by Olson, Crenson, Mayhew, and Fiorina and Noll have argued, neither producers nor politicians have much incentive to provide collective goods. ${ }^{11}$ Politicians cannot distribute collective benefits to their supporters while excluding their opponents; collective goods are thus of little use to them in building political coalitions. ${ }^{12}$ The constituents, moreover, have every reason to believe that the politicians cannot control government policies that apply to the development strategies of the nation as a whole, or that affect the national economic structure in its entirety; their political representative represents too small a fraction of the government to have significant influence over such matters. But, on issues like the location of roads, bridges, and clinics-in matters of spoils, that is-they believe that their representative should be decisive in determining the distribution of these things within their constituencies. Although the benefits from tariff reform may exceed the benefits to be gained by the digging of a well, the expected return on attempts to influence the representative's stand on the latter kind of issue could easily exceed the expected returns on attempts to influence his position on such matters as tariff policy. There is thus less of an incentive to engage in influence attempts in the areas of tariffs, taxes, or pricing policies than there is to engage in the distribution of spoils. And the consonance in the incentives facing

${ }^{10}$ This argument appears most strongly in O'Brien (chaps. 3, 5, and 6), and Dunn and Robertson (chap. 8).

${ }^{11}$ Mancur Olson, Jr., The Logic of Collective Action (Cambridge: Harvard University Press 1965); Matthew A. Crenson, The Un-Politics of Air Pollution (Baltimore, Md.: The Johns Hopkins Press I97I); David R. Mayhew, Congress: The Electoral Connection (New Haven and London: Yale University Press 1974); Morris P. Fiorina, Congress: Keystone of the Washington Establishment (New Haven and London: Yale University Press 1977); and Morris P. Fiorina and Roger G. Noll, "Voters, Bureaucrats, and Legislators: A Rational Choice Perspective on the Growth of Bureaucracy" (California Institute of Technology, Social Science Working Paper No. 159, June 1977). The approach is perhaps most completely and convincingly developed by Barry Weingast in his "A Representative Legislature and Regulatory Agency Capture," Ph.D. diss. (California Institute of Technology I977).

12 In parliamentary systems, the party in power can clearly behave like the single politican. It controls the government, even though it does not hold roo percent of the seats. Manipulating the supply of divisible benefits, such as schools and clinics, rather than the supply of collective goods, it can then behave like a discriminating monopolist and provide services only to those who are willing to vote for it. As Dunn and Robertson show, the governing CPP behaved precisely in this way in the cocoa-growing regions of Ghana and so broke the hold of the political opposition (chap. 8, and esp. pp. 327 ff.). 
politicians and the electorate may be sufficient to displace the former set of issues with the latter on the rural political agenda.

Vigorous political competition continues; resources are channeled into the countryside in the form of public projects; and the basic policies that determine the collective standing of the peasantry remain largely off the political agenda, with the result that the peasants remain poor. The diverse images of the state as monolith and as arena for political competition; of peasants as victims and as beneficiaries; of political action and lack of reward; of peasants as rational political actors, and as losers in the political economies of the new nations-these conflicting images appear to be reconcilable when the significance of the distinction between purely public goods and divisible public benefits is recognized. $^{13}$

\section{ConcLusion}

In this paper, I have explored the dominant topics that characterize micro-level studies of rural behavior in the developing nations. In so doing, I have examined the relationship of the rural communities to the state and to the market. I have also looked within the rural sector and examined the structure of rural communities, the way in which that structure influences the allocation of resources, and the variety of models of individual behavior that have been applied to the study of peasants. I have also discussed some of the ethical issues that arise in the literature, and attempted to resolve some of the basic dilemmas that intrude so strikingly at a variety of points.

Obviously, this new literature is securely launched. It has already established a coherent set of interests, provoked well-focused debates, and investigated in depth several regions of the world whose economic fortunes influence the world markets in agriculture and whose political fortunes have affected us all. In addition, it has given rise to a series of topics for further investigation; these topics constitute the research agenda of this emerging genre.

Relationships with the state and the market: The relationship between the rural sector and the state has barely been examined. The developing nations are overwhelmingly rural in makeup. Why do politicians in these nations so often choose policy positions that appear to violate the interests of a vast majority of their citizens? In the developed nations,

\footnotetext{
13 Perhaps the seminal statement of this distinction is contained in Theodore J. Lowi, "American Business, Public Policy, Case-Studies, and Political Theory," World Politics, xvi (July I964), 677-715.
} 
farmers are a minority and yet are subsidized by the state; in the developing world, they are a majority and yet appear on balance to be heavily taxed. What explains this paradox?

With respect to the rural dwellers' encounter with the market, I would advocate giving up on the interminable debate about which is more important-what is given up in the market or what is received in exchange. More meaningful, surely, are empirical investigations of the actual distribution of the gains from peasant production. As part of their micro-studies, scholars should investigate such subjects as the structure and organization of rural markets, the system and incidence of taxation, shifts in the terms of trade between agricultural and industrial products, and changes in the levels, sources, and terms of agricultural credit. Equally as important, they should analyze the manner in which the political system is used to determine these things.

It should be noted that, in studying the market, all of the books restrict themselves to the market for produce but largely ignore the market for labor. That is a major omission, for in many of the rural communities, immigrants represent a major political faction. Urban migrants often return to these communities with new political preferences, and frequently organize to promote their political ideals. Moreover, the fact that emigration is possible places a lower bound on the level of political and economic exploitation that can be achieved by rural elites; variations in the attractiveness of this option thus can help to account for variations in the level of exploitation achieved by rural elites in different peasant communities.

Relationships within the peasant communities: From contributors with anthropological interests, we have a sense of the structure of rural communities in the developing nations; from those more committed to traditional political science, we have a sense of the national political structures. Following in the footsteps of Barrows and O'Brien, we should examine the political alliances between local and national elites and the material considerations that bind such coalitions. Even more, we need to investigate the manner in which the rural elites represent (or fail to represent) the interests of their clients in the bureaucratic process of policy formation, particularly in the areas of planning, taxation, and public expenditure. We know surprisingly little about interestgroup politics, insofar as they affect agricultural production in ThirdWorld nations.

Given the variety of models of peasant behavior that are now available, we need a further elaboration and testing of them. For example, a model of utility maximization is vacuous until it specifies the objects 
that give people satisfaction, and the relative weight they place upon them; the variety of local peasant cultures will allow the development of a variety of different specifications. Similarly, "safety first" models are also vacuous until they specify the nature of the minimum which people seek to protect and the degree to which they seek such protection. A more complete working-out of these models, and the beginnings of some rigorous testing, represent obvious next steps in the literature.

In the investigation of ethical considerations, it is clear that perhaps the most attractive direction in which to move is the one staked out by Scott: the investigation of the peasants' own ethical systems. After all, it is their conceptions of justice, fairness, equity, and due process that will largely determine their response to the forced levies and economic redistributions which inevitably occur as part of the development process. 